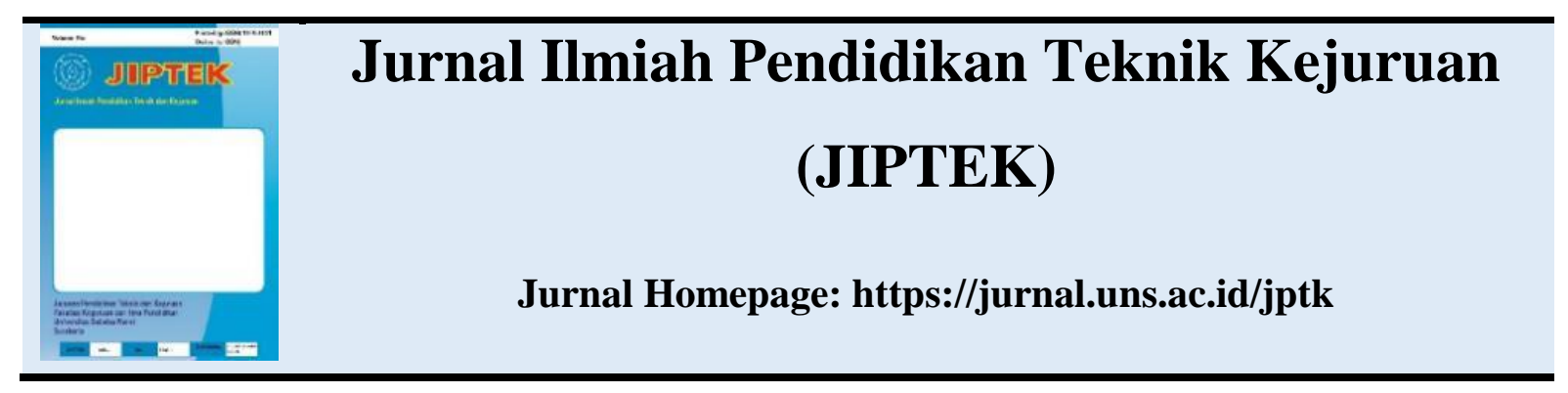

\title{
PEMANFAATAN FITUR LESSON QUIZIZZ SEBAGAI ALTERNATIF MEDIA PEMBELAJARAN INTERAKTIF
}

\author{
Cakra Aminuddin \\ Program Profesi Guru, TKI, Universitas Sebelas Maret Surakarta \\ Jalan Ahmad Yani 200 Surakarta \\ Email: cakra.amin@gmail.com
}

\begin{abstract}
ABSTRAK
Pemanfaatan fitur lesson pada aplikasi quizizz yang diharapkan dapat sebagai alternatif media pembelajaran online bagi peserta didik. Selain dapat secara langsung melihat tingkat keaktifan peserta didik dalam menjalani proses pembelajaran juga sebagai media evaluasi bagi peserta didik yang dapat dipantau secara langsung dan simultan oleh pendidik. Hal ini dalam rangka untuk menindaklanjuti terhadap penurunan tingkat keaktifan peserta didik di masa pandemi seperti saat ini. Tingkat keaktifan peserta didik diukur dengan menghitung jumlah response peserta didik terhadap media pembelajaran dan jumlah partisipasi peserta didik pada post test setelah proses review media pembelajaran. Pada pelajaran Administrasi System Jaringan kelas XII KJ B SMK Negeri 1 Rembang, tingkat keaktifan peserta didik mengalami penurunan jika dibandingkan dengan awal pembelajaran jarak jauh dilaksanakan, sehingga diperlukan sebuah alternatif media pembelajaran yang inovatif dan tidak monoton untuk menaikkan tingkat keaktifan peserta didik.
\end{abstract}

Kata kunci: fitur lesson quizizz

\section{ABSTRACT}

Utilization of the lesson features in the Quizizz application which is expected to be an alternative online learning media for students. Apart from being able to directly see the level of activeness of students in undergoing the learning process it is also an evaluation medium for students that can be monitored directly and simultaneously by educators. This is in order to follow up on the decrease in the level of activity of students in a pandemic like this time. The level of student activity is measured by calculating the number of students 'responses to the learning media and the number of students' participation in the post test after the learning media review process. In the Network System Administration lesson for class XII KJ B SMK Negeri 1 Rembang, the level of activity of students has decreased when compared to the beginning of distance learning, so an alternative learning media is needed that is innovative and not monotonous to increase the level of student activity.

Keywords: Lesson Quizizz feature

JIPTEK, Vol. 13 No. 2 , 2020

DOI: http://dx.doi.org/10.20961/jiptek.v13i2.45611 


\section{PENDAHULUAN}

Pada masa pandemi seperti saat ini, tingkat keaktifan peserta didik semakin hari semakin menurun. Ditandai dengan kehadiran peserta didik dan pembelajaran Synchronous yang menurun jika dibandingkan dengan awal pandemi ini. Hal ini akan berakibat dengan menurunnya pemahaman terhadap pembelajaran yang disampaikan oleh pendidik di dalam proses pembelajaran, yang nantinya akan berdampak pada menurunnya kualitas SDM yang dihasilkan oleh sekolah.

Untuk mengatasai permasalahan menurunnya keaktifan peserta didik, diperlukan sebuah media pembelajaran yang inovatif dan tidak monoton. Selama ini penggunaan media pembelajaran hanya sebatas slide power point yang dibagikan oleh pendidik ke group chat kelas atau melalui platform digital seperti Google Classroom.

Keaktifan peserta didik di dalam proses pembelajaran menurut Paul B. Diedrich (Sardiman, 2001, p.101) dapat dijabarkan sebagai berikut:

a. Visual activities, contohnya: membaca media pembelajaran dan memperhatikan presentasi.

b. Oral activities, contohnya: bertanya, menyampaikan pendapat, dan diskusi.

c. Listening activities, contohnya: mendengarkan baik didalam proses pembelajaran atau tukar pendapat dengan peserta didik lain.

d. Writing activities, contohnya: membuat laporan dan membuat notulen presentasi. e. Drawing activities, contohnya: menggambar topologi dan membuat grafik di dalam laporan.

f. Motor activities, contohnya: melakukan percobaan praktik di dalam pembelajaran.

g. Mental activities, contohnya: menanggapi pernyataan teman, mengambil keputusan dalam penugasan.

h. Emotional activities, contohnya: bersemangat di dalam pembelajaran, bosan di dalam pembelajaran.

\section{METODE PENELITIAN}

A. Subject Penelitian

Subjek Penelitian ini adalah siswa kelas XII TKJ B tahun ajaran 2020/2021 yang mengikuti mata pelajaran Administrasi System Jaringan dengan jumlah siswa 35 , terdiri dari 31 siswa putri dan 4 siswa putra.

B. Pelaksanaan Penelitian

Penelitian ini dilakukan dengan mengamati tingkat kuantitatif terhadap aktivitas peserta didik. Yang pertama adalah menghitung jumlah review terhadap media pembelajaran yang harus peserta didik upload melalui Google Classroom, yang kedua adalah menghitung jumlah partisipasi Post Test melalui quizizz setelah melakukan pengumpulan hasil review terhadap materi yang sudah dibagikan.

C. Teknik Analisis Data

Analisis yang digunakan dalam penelitian ini adalah analisis terhadap kuantitatif response dengan langkah sebagai berikut: 
a. Berdasarkan data hasil observasi, nilai keaktifan peserta didik dinilai berdasarkan jumlah response terhadap media pembelajaran yang diupload dan jumlah keikutsertaan peserta didik di dalam post test.

b. Setelah diperoleh jumlah nilai keaktifan peserta didik terhadap media pembelajaran yang disampaikan dan diresponse oleh peserta didik, berikutnya adalah membandingkan dengan jumlah skor maksimal yang diharapkan.

D. Indikator Keberhasilan

Keaktifan belajar peserta didik dihitung berdasarkan indikator keaktifan belajar yaitu response peserta didik terhadap media pembelajaran dan keikutsertaan peserta didik di dalam post test. Banyaknya siswa yang memperoleh kategori keaktifan belajar adalah $75 \%$. Dalam hal ini adalah tingkat response anak terhadap slide power point dan tingkat keikutsertaan peserta didik di dalam Post Test setelah anak mereview media pembelajaran.

\section{HASIL PENELITIAN DAN PEMBAHASAN}

Dari hasil penelitian yang dilakukan dengan membandingkan antara penggunaan media konvensional dengan slide power point yang dibagikan melalui Google Classroom dan menggunakan fitur Lesson pada quizizz. Dapat disimpulkan bahwa dengan menggunakan fitur Lesson pada quizizz akan meningkatkan tingkat keaktifan peserta didik baik dalam aktivitas memperhatikan media pembelajaran dan tingkat keikutsertaan peserta didik di dalam post test setelah mereview media pembelajaran. Kesimpulan tersebut dapat dilihat di dalam tabel di bawah ini

\begin{tabular}{lccc} 
Media & $\begin{array}{c}\text { Tabel 1. Tabel Keaktifan } \\
\text { Jumlah } \\
\text { Peserta } \\
\text { Didik }\end{array}$ & $\begin{array}{c}\text { Jumlah } \\
\text { Respons }\end{array}$ & $\begin{array}{c}\text { Jumlah } \\
\text { Keikutse } \\
\text { rtaan } \\
\text { Post Test }\end{array}$ \\
\hline $\begin{array}{l}\text { Google } \\
\text { Classroo } \\
\text { m }\end{array}$ & 35 & $\begin{array}{c}20 \\
\text { peserta }\end{array}$ & $\begin{array}{c}22 \\
\text { peserta }\end{array}$ \\
\hline Quizizz & 35 & $\begin{array}{c}29 \\
\text { peserta }\end{array}$ & $\begin{array}{c}29 \\
\text { peserta }\end{array}$ \\
\hline
\end{tabular}

Dari tabel keaktifan di atas terlihat bahwa jumlah response siswa terhadap media pembelajaran mengalami kenaikan yang awalnya 20 peserta didik menjadi 29 peserta didik ketika menggunakan fitur Lesson pada quizizz atau naik $25,7 \%$. Sedangkan untuk partisipasi peserta didik dalam post test mengalami kenaikan dimana jumlah awal diikuti oleh 22 peserta naik menjadi 29 peserta ketika menggunakan quizizz atau naik $20 \%$. Dari hasil pembahasan ini, ditampilan dalam bentuk grafik seperti Gambar 1 dibawah ini.

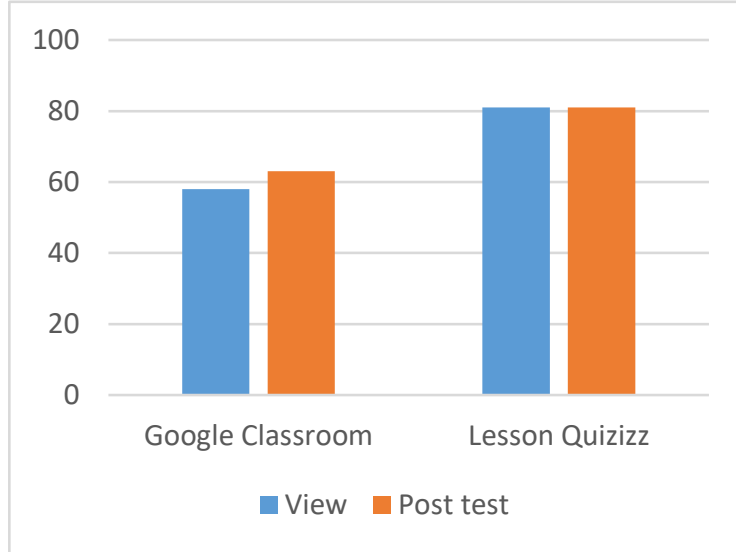

Gambar 1. Grafik keaktifan 


\section{SIMPULAN DAN SARAN}

\section{Simpulan}

Berdasarkan hasil penelitian di atas, dapat disimpulkan bahwa tingkat keaktifan peserta didik di masa pandemi saat ini semakin menurun, dimana parameter yang digunakan adalah tingkat review terhadap media pembelajaran yang di upload oleh peserta didik dan tingkat keikutsertaan post test peserta didik setelah melakukan review terhadap media pembelajaran. Untuk itu perlu diberikan sebuah alternatif media pembelajaran yang dapat menaikkan tingkat keakfifan peserta didik yang salah satunya menggunakan quizizz, peningkatan keaktifan peserta didik ketika menggunakan quizizz tersaji pada di tabel 1. Dari data yang ditampilan pada tabel 1 tersebut terlihat bahwa untuk jumlah response peserta didik terhadap media pembelajaran dan tingkat partisipasi post test peserta didik mengalami kenaikan ketika menggunakan fitur lesson quizizz sebagai pengganti media pembelajaran yang sebelumnya menggunakan Google Classroom.

\section{Saran}

Diharapkan pendidik lebih variatif dalam memilih dan memberikan media pembelajaran, terutama media pembelajaran yang memberikan interaktif kepada peserta didik secara langsung untuk meningkatkan keaktifan peserta didik di dalam proses pembelajaran.

\section{DAFTAR PUSTAKA}

Dimyati dan Mudjiono. 2009. Belajar dan Pembelajaran. Jakarta: Rineka Cipta.

Chiang, H. Lee,. 2016. The Effect of Project Based Learning on Learning Motivation and Problem-Solving Ability of Vocational High School Student. International Journal of Information and Education Technology, Vol. 6 No. 9.

Arifin, Zaenal. 2013. Dasar-dasar Penulisan Karya Ilmiah. Jakarta: Grasindo.

Djamarah, Syaiful Bahri. 2010. Strategi Belajar Mengajar. Jakarta: Rineka Cipta.

Eric Kunto Aribowo. Dua Cara Membuat Presentasi Interaktif di Quizizz. 19 September 2020. http://www.erickunto.com/2020/09/19/ dua-cara-membuat-presentasiinteraktif-di-quizizz/. 